\title{
The Role of Consumer Innovativeness in Mobile Commerce Usage: A Comparison of Two Emerging Countries: An Abstract
}

\author{
Abdul R. Ashraf, Narongsak (Tek) Thongpapanl, and Ali Anwar
}

\begin{abstract}
Mobile commerce has not only seen remarkable growth in recent years but also shows promising trends for the future. Research has, however, not paid enough attention to understand the factors that determine the perceived value of $\mathrm{m}$-commerce for consumers. This study advances the literature by providing a framework of the drivers and barriers to m-commerce value, in India and Pakistan, countries with immense m-commerce potential. This context also provides an opportunity to observe how consumers' $\mathrm{m}$-commerce behavior differs across different countries, as determinants like perceived risk and cost are likely to have a more pronounced effect in these relatively nascent markets. The proposed framework connects m-commerce value, and in turn the actual usage to their key determinants including ubiquity, risk, and cost, while investigating the moderating effects of personal innovativeness. The results reveal that ubiquity has a positive impact on perceived $\mathrm{m}$-commerce value, while risk and cost have a negative influence. We also find a significant moderating effect of innovativeness on all three drivers of value. The results further show that perceived value positively affects m-commerce usage and is strengthened by consumer innovativeness. We discuss theoretical and managerial implications of the results, discussing how retailers can enhance their marketing strategies, particularly in emerging m-commerce markets.
\end{abstract}

References Available Upon Request

\footnotetext{
A.R. Ashraf • N. (Tek). Thongpapanl $(\varangle) \bullet A$. Anwar $(\varangle)$

Brock University, St. Catharines, Canada

e-mail: arehman@brocku.ca; tek@brocku.ca; aa15zr@brocku.ca
} 